\title{
Impact of AM Fungi and Azotobacter in the Alleviation of Cd-Induced Growth Reduction and Activity of Antioxidants in Coriandrum Sativum $\mathbf{L}$
} Shahla Faizan"

Environmental Physiology laboratory, Department of Botany, Aligarh Muslim University, Aligarh 202002, Uttar Pradesh, India

DOI:10.36348/SJLS.2019.v04i08.002 | Received: 28.04.2019 | Accepted: 07.05.2019 | Published: 24.09.2019

*Corresponding author: Shahla Faizan

Abstract

The aim of the present study was to evaluate the role of arbuscular mycorrhizal (AM) fungi and Azotobacteron growth, oxidative effect and antioxidant defense mechanisms under cadmium $(\mathrm{Cd})$ stresses in Coriandrum sativum L. (Coriander). Treatments consisted of mycorrhizal and Azotobacter treatments and threeconcentrations of cadmium treatments (0,50and $100 \mathrm{mg} \mathrm{Cd} \mathrm{kg}$ of soil). Metal induced oxidative damage through increased lipid peroxidation. Superoxide dismutase (SOD), catalase (CAT) and peroxidase (POX) increased under stress and it was found that there was a direct correlation between root length, shoot length, plant fresh weight and plant dry weight and the activity of these enzymes in concentration dependent manner. The activity of antioxidants and growth increased in mycorrhizal and Azotobacter stressed plants. However, the combination of mycorrhiza (AMF) and Azotobacteracted synergistically and significantly arrested lipid peroxidation and led to increased growth as well as activity of activity of antioxidants. The interactions of cadmium and biofertilizers proved to be synergistic and the antioxidant activities further increased indicated the positive role of biofertilizers in increasing the antioxidant activity thereby decreasing oxidative stress and stimulating growth. Therefore, biofertilizers are advisable to enhance the tolerance to cadmium stress in medicinally important coriander.

Keywords: Azotobacter, Antioxidants, Coriandrum Sativum, mycorrhizal.

Copyright @ 2019: This is an open-access article distributed under the terms of the Creative Commons Attribution license which permits unrestricted use, distribution, and reproduction in any medium for non-commercial use (NonCommercial, or CC-BY-NC) provided the original author and source are credited.

\section{INTRODUCTION}

Heavy metal stress is one of the major abiotic stresses in recent decades because unlike other organic pollutants, they are not degraded and converted into harmless compounds via biological processes [1]. Its persistence in the environment for a long time pose a risk for primary as well as secondary consumers and ultimately to humans through the entry into the food chain [2]. Cadmium $(\mathrm{Cd})$ is one of the most toxic, nonessential, persistent environmental toxicant [3, 4], mobile and a non different indirect mechanisms. It is emanated in the arable field mainly due to the application of pesticides, industrial processes, fossil fuel combustion, cement manufacture, non-ferrous metal production, irrigation with wastewater, sewage sludge, metal-containing pesticides, municipal- based composts and phosphate fertilizers [5-10] and from the soil, despite its non-essentiality, it is readily taken up and translocated upward by the plants where it causesreduction of growth as well as phytotoxicitythroughthe production of toxic oxygen derivatives [11] and alsoa potential risk for human health when transferred from crops to human diet. Cd stress disrupts cellular homeostasis and enhances the generation of reactive oxygen species (ROS) such as superoxide anion $\left(\mathrm{O}_{2} \cdot{ }^{-}\right)$, hydroxyl radical $\left({ }^{\circ} \mathrm{OH}\right)$, singlet oxygen $\left({ }^{1} \mathrm{O} 2\right)$ and hydrogen peroxide $\left(\mathrm{H}_{2} \mathrm{O}_{2}\right)$ in plants [12]. Oxidative stress would arise if the balance between ROS generation and removal was broken [13] which induces damage to the biomolecules, causes lipid peroxidation by the production of malondialdehyde (MDA) which is one of the decomposition products of polyunsaturated fatty acids of membranes [14-20], disruption of some of the metabolic pathways such as electron transport chain and ATP production [21, 22] and a cumulative adverse effects on plant growth and yield [6, 23, 24]. Plants have the ability to combat negative consequences of heavy-metal stress and protect the cells from oxidative damage by complex ROS scavenging mechanisms at the molecular and cellular levels due to a series of detoxification reaction catalyzed by efficient antioxidant defense systems such as CAT, SOD and POD which inhibit the oxidation of biomolecules, oxidative chain reactions and cellular oxidative damage [25-29]. Superoxide dismutase (SOD; EC, 1.15.1.1) is a key enzyme of primary line of 
defense that dismutates superoxide radicals to $\mathrm{H}_{2} \mathrm{O}_{2}$ and protects cells against oxidative stress [30, 31] Further, the accumulation of $\mathrm{H} 2 \mathrm{O} 2$ is restricted through the action of catalase (CAT; EC, 1.11.1.6) [32, 33] and peroxidase (APX; E.C.1.11.1.11.) whichhas to be further detoxified [15] to water and $\mathrm{O}_{2}[34,35]$.

Mycorrhiza areobligate symbionts, nonpathogenic fungi, potential phosphate-solubilizing biofertilizers, a cheap and environment friendly alternative to expensive chemical fertilizers [36]. These are the most ancient and wide spread plant strategies to facilitate plant growth, enhance resistance to cope with the environmental stress and are able to regulate genes which cause accumulation of ROS in order to mitigate HM-induced oxidative stress [25, 37-40], enhance plant mineral nutrition, water acquisition [41], increase biomass and survival rate under different environmental stresses [42-46, 28].

Azotobacter is a free-living, gram negative aerobic bacteria that can be an alternative to chemical fertilizers and pesticides [47], increase plant growth by synthesizing biologically active substances [48], increase root surface area, produce phytohormone precursors in $\mathrm{N}$-free media $[49,50]$, provide $\mathrm{N}$ to the plants through $\mathrm{N}_{2}$ fixation [51], provide essential nutrients [52, 53], increase the uptake of [54-56], synthesizes antioxidants to scavenge the toxicity of ROS generated by plants and play a pivotal role in protecting the plants from oxidative stress [57-59].

Coriander (Coriandrum sativum L.) is an important spice crop of family Apiaceae that has nutritional as well as medicinal properties and occupies a prime position in flavoring substances. Its volatile oil is rich in beneficial phytonutrients and the seeds are used as antispasmodic, carminative, stimulant, fungicidal, stomachic, hypoglycemic, hypolipidemic, antibacterial, antimutagenic, insecticidal activity and aflatoxin controlling effects. It is also used as an antioxidant in the control of swellings, diarrhea, mouth ulcers, anemia, menstrual disorders, small pox, eye care, and conjunctivitis and skin disorders.

The positive synergistic interactions among components of the tripartite symbiotic association (AMF-Azotobacter- Coriandrum sativum L.) alleviated toxic effects of ROS and maximized plant growth, its nutrition and yield [60]. However, this interaction under $\mathrm{Cd}$ stress has not yet explored and less attention was paid on this aspect. Therefore, proposed study was conducted as an acceptable approach, safe for human consumption than chemical fertilizers and also to appraise the effectiveness of synergistic microbes in the amelioration of tolerance in coriander against the inhibitory effects of cadmium.

\section{MATERIALS AND METHODS}

Seeds of coriander ( $C$. sativum L.) were obtained from National Seed Corporation Ltd., New Delhi, India and the authentic culture of AM fungi and Azotobacter were procured from the Division of Microbiology, Indian Agriculture Research Institute, New Delhi. The seeds were surface sterilized with $0.5 \%$ hypochlorite for $5 \mathrm{~min}$, rinsed thoroughly in double distilled water for 5-6 times and soaked overnight in sterile water for $12 \mathrm{~h}$ at $4{ }^{\circ} \mathrm{C}$ for uniform germination. Azotobacter culture was applied on the surface sterilized seeds by dipping in a sugary solution of bacterial powder containing Azotobacter chroococcum cells, $5 \times 10^{8} \mathrm{~g}^{-1}$ prepared in the ratio of $1: 1$ for $15 \mathrm{~min}$. After that, the seeds were dried for $30 \mathrm{~min}$ in shade at a temperature of $20^{\circ} \mathrm{C}$.Five $\mathrm{kg}$ soil composed of peat and compost $(4: 1$, w/w) mixed with sand $(3: 1, w / w)$ was filled in 23-cm-diameter earthen pots and mixed thoroughly with appropriate amount that is $0,326.16$ and $652.28 \mathrm{mg} \mathrm{CdCl}_{2} \mathrm{~kg}$ soil to achieve $0,50,100 \mathrm{mg}$ $\mathrm{Cd} \mathrm{kg}{ }^{-1}$ of soil $\left(\mathrm{Cd}_{0}, \mathrm{Cd}_{50}\right.$ and $\left.\mathrm{Cd}_{100}\right)$ respectively and watered on alternate days. Spores were applied at the rate of thousand spores per pot as a thin layer below the seeds before sowing. The application rate was same in combined inoculation also. Plants were sampled at three stages (30, 60 and 90 DAS).

A completely randomized block design experiment with five replicates was arranged in the net house of Department of Botany, Aligarh Muslim University, Aligarh, India during September-February 2009-2010 under natural day/night condition (Photo synthetically active radiation $>950 \mathrm{mmol} \mathrm{m}^{-2} \mathrm{~s}^{-1}$, average day and night temperature of $21 \pm 3$ and $12 \pm 2{ }^{\circ} \mathrm{C}$ respectively and relative humidity $75 \pm 5 \%$ ) which included two mycorrhizal treatments (with mycorrhizal fungi ' $\mathrm{M}_{+}$"' and non-mycorrhizal fungi' $\mathrm{M}_{-}$"), two Azotobacter treatments (with Azotobacter " $\mathrm{A}_{+}$", and Azotobacter "A.") and three levels of cadmium treatments i.e. $\mathrm{CdCl}_{2}$ at 0,50 and $100 \mathrm{mg} / \mathrm{kg}$ of soil); The total nine treatments $\mathrm{T}_{0}-\mathrm{Cd}_{0} \mathrm{M}_{-} \mathrm{A}_{-}, \mathrm{T}_{1}-\mathrm{Cd}_{0} \mathrm{M}_{+} \mathrm{A}$ $, \mathrm{T}_{2}-\mathrm{Cd}_{0} \mathrm{M}_{-} \mathrm{A}_{+}, \quad \mathrm{T}_{3^{-}} \quad \mathrm{Cd}_{0} \mathrm{M}_{+} \mathrm{A}_{+}, \mathrm{T}_{4^{-}} \mathrm{Cd}_{50} \mathrm{M}_{+} \mathrm{A}_{-}, \mathrm{T}_{5^{-}}$ $\mathrm{Cd}_{50} \mathrm{M}_{-} \mathrm{A}_{+}, \mathrm{T}_{6}-\mathrm{Cd}_{50} \mathrm{M}_{+} \mathrm{A}_{+}, \mathrm{T}_{7}-\mathrm{Cd}_{100} \mathrm{M}_{+} \mathrm{A}_{-} \mathrm{T}_{8^{-}} \mathrm{Cd}_{100}$ $\mathrm{M}_{+} \mathrm{A}, \mathrm{T}_{9}-\mathrm{Cd}_{100} \mathrm{M}_{+} \mathrm{A}_{+}$.

\section{Measurements of Growth}

Plants were uprooted and growth characteristics such as shoot length, root length, plant fresh weight and plant dry weight were measured on a meter scale after 30 days of treatment. Shoot and root length were measured on meter scale. These plants were blotted in blotting sheets to remove the adhering water and weighed on electronic balance to record their fresh weight. Dry weight was determined after drying the samples in an oven for about 72 hours at $80^{\circ} \mathrm{C}$ till constant weight.

\section{Determination of Lipid Peroxidation}

The level of lipid peroxidation products in leaves was expressed by estimating thiobarbituric acid 
reactive substances (TBARS content) expressed as equivalents of malondialdehyde (MDA; a byproduct of lipid peroxidation) using using 2-thiobarbituric acid (TBA) [61]. Frozen samples were taken and homogenized with two volumes of ice-cold $0.1 \%$ (w/v) trichloroacetic acid (TCA) and homogenate was centrifuged at $12,000 \mathrm{~g}$ for $15 \mathrm{~min}$ at $4{ }^{\circ} \mathrm{C}$. Assay mixture containing $2 \mathrm{ml}$ aliquot and $2 \mathrm{ml}$ of $0.6 \%$ thiobarbituric acid (TBA) in 10\% TCA was heated at $95^{\circ}$ for $30 \mathrm{~min}$ and rapidly cooled in an ice bath to terminate the reaction. After centrifugation $(12,000 \mathrm{~g}$ for $15 \mathrm{~min}$ at $\left.4{ }^{\circ} \mathrm{C}\right)$, absorbance $(532 \mathrm{~nm})$ was measured and values corresponding to nonspecific absorption $(600 \mathrm{~nm})$ were subtracted. The total MDA content was calculated using the extinction coefficient of 155 $\mathrm{mM}^{-1} \mathrm{~cm}^{-1}$ and expressed as Nano mole MDA per gram DW.

\section{Extraction and Estimation of Antioxidatant Enzymes}

Antioxidant enzymes were examined according to Zhang [62] with some modifications. The fresh leaves $(0.3 \mathrm{~g})$ were homogenizedin $5 \mathrm{ml}$ of 50 $\mathrm{mM}$ potassium phosphate buffer $(\mathrm{pH} 7.8)$ containing $0.5 \mathrm{mM}$ EDTA and centrifuged at $10,000 \mathrm{rpm}$ at $4{ }^{\circ} \mathrm{C}$ for $15 \mathrm{~min}$ and the supernatant obtained were utilized for enzyme assays [63]. Superoxide dismutase (SOD, EC 1.15.1.1) activity was assayed by monitoring the inhibition of photochemical reduction due to nitroblue tetrazolium (NBT) using the method of Sen Gupta et al., [64]. A $3 \mathrm{ml}$ of reaction mixture was prepared by taking $200 \mathrm{mmolL}^{-1}$ methionine, $2.25 \mathrm{~m} \mathrm{molL}^{-1}$ nitroblue tetrazolium (NBT), $3 \mathrm{~m} \mathrm{molL}^{-1}$ EDTA, $100 \mathrm{~m}$ $\mathrm{molL}^{-1}$ potassium phosphate buffer, $60 \mu \mathrm{molL}^{-1}$ riboflavin, distilled water and enzyme extract and it was illuminated with $30 \mathrm{~W}$ florescent lamps for $15 \mathrm{~min}$ at $28{ }^{\circ} \mathrm{C}$. Blank and controls were run in the same manner but without illumination and enzyme. A unit of SOD is defined as the amount of enzyme required to cause $50 \%$ inhibition of the reaction of NBT measured at $560 \mathrm{~nm}$. The activity of CAT (CAT, EC 1.11.1.6) was analyzed according to Aebi [65] in $3 \mathrm{ml}$ of a reaction mixture containing $50 \mathrm{mM}$ potassium phosphate buffer $(\mathrm{pH}$ 7.0), $2 \mathrm{mM} \mathrm{Na}_{2}$-EDTA, $10 \mathrm{mM} \mathrm{H}_{2} \mathrm{O}_{2}$ and $0.1 \mathrm{ml}$ of the enzyme extract. Decrease in absorbance was measured at $240 \mathrm{~nm}$ as a consequence of $\mathrm{H} 2 \mathrm{O} 2$ consumption for 1 min (coefficient of absorbance of $39.4 \mathrm{mM}^{-1} \mathrm{~cm}^{-1}$ ). The activity of Peroxidase was estimated by the method of Bergmeyer et al., [66]. In a $30.1 \mathrm{ml}$ of reaction mixture consisting of pyrogallol phosphate buffer( $\mathrm{pH} 6.8), 1 \%$ $\mathrm{H} 2 \mathrm{O} 2$, deionized water and enzyme extract was incubated at $30^{\circ} \mathrm{C}$ Change in absorbance, due to catalytic conversion of pyrogallol to perpurogallin, was noted at an interval of $20 \mathrm{~s}$ for $2 \mathrm{~h}$ at $420 \mathrm{~nm}$. A control set was prepared by distilled water instead of enzyme extract. The change in absorbance per seven minutes (4 times) over the linear portion of the curve was measured and this value was used in the calculation.

\section{Statistical Analysis}

Data of various parameters were subjected to analysis of variance (ANOVA) for two factor pot culture experiment i.e., microbial inoculants and cadmium stress, using SPSS software version 10.0. Duncan's multiple range test (DMRT) at 0.05 level of probability was used to evaluate the difference among treatment means. The ' $F$ ' test was applied to assess the significance of data at $5 \%$ level of probability $(\mathrm{P} \leq 0.05)$. A correlation coefficient value (r) was also undertaken.

\section{RESULTS}

Results pertaining to the effects of various concentrations of $\mathrm{Cd}$ on the growth attribute such as shoot length, root length, plant fresh weight and plant dry weight after 45 days of sowing was maximally and significantly reduced by the increasing concentration of cadmium. However, maximum reduction of toxicity in growth was reflected by $100 \mathrm{mg} \mathrm{Cd} \mathrm{kg}^{-1}$ soil (Table-1). Roots were found to be more sensitive to toxic effects of $\mathrm{Cd}$ than shoots. The highest $\left(100 \mathrm{mg} \mathrm{Cd} \mathrm{kg}^{-1}\right.$ soil) and moderate $\left(50 \mathrm{mg} \mathrm{Cd} \mathrm{kg}^{-1}\right.$ soil) level of metal decreased root length by $22.8 \%, 42.9 \%$, shoot length by $19.3 \%, 36.8 \%$, plant fresh weight by $17.0 \%, 51.6 \%$ and that of plant dry weight by $22.9 \%, 52.0 \%$ respectively, over their controls. However, Dual inoculation of AMF and Azotobacter made the plants more adaptable to the stressed conditions. They together proved to be synergistic in the alleviation of toxic effects of cadmium stress and enhanced the growth attributes significantly as compared to their single inoculation. Their co-inoculation caused an increase of root length by $24.0 \%$, shoot length by $12.8 \%$, plant fresh weight by $71.0 \%$ and that of plant dry weight by $31.0 \%$ respectively, over their respective control at $100 \mathrm{mg} \mathrm{Cd}$ $\mathrm{kg}^{-1}$ soil (Table-1).

Two way ANOVA showed that individual effects of inoculation and cadmium were significant $(\mathrm{p}$ $<0.05$ ) for all the measured parameters except interaction (inoculation $\times \mathrm{Cd}$ ) effects on growth. The value for correlation between different parameters was presented in Table-2 showing positive correlation between various growth parameters.

In general, $\mathrm{Cd}$ had significant effects on the antioxidant activities of coriander. Metal stress significantly increased the antioxidant activity. In general, the toxicity of $100 \mathrm{mg} \mathrm{Cd} \mathrm{kg}{ }^{-1}$ soilwas much higher and led to higher increase in enzyme activity as compared to $50 \mathrm{mg} \mathrm{Cd} \mathrm{kg}{ }^{-1}$ soil. However, with the introduction of AM fungi and Azotobacter in the root, there was a significant improvement in this parameter. Their combined interactions further enhanced the activity of enzymes which clearly indicated the positive synergistic interaction of microbes in decreasing oxidative stress. Since, bacterial symbiosis and mycorrhizal colonization were relatively tolerant to different concentrations of metals, their effective symbiosis might have been responsible for bringing 
tolerance in plants of heavy metal stress (SOD Fig-1A; CAT Fig-1B and POX Fig-3C).

In the present study, SOD activity had significant increase in the leaves of coriander exposed to $50 \mathrm{mg} \mathrm{Cd} \mathrm{kg}{ }^{-1}$ soil, however it further turned to decline at the highest dose of $100 \mathrm{mg} \mathrm{Cd} \mathrm{kg} \mathrm{soil}^{-1}$. Application of either AM fungi or Azotobacter singly increased the activity of this enzyme. Whereas, in case of co-inoculated plants, SOD activity showed a sharp and significant increase with the increase in cadmium concentration which reached its maximum level at 100 mg Cd kg-1 soil (Fig-1A).

The CAT activity enhanced significantly with the increase in the concentration of Cadmium in the soil in un inoculated control plants. The dual application of both the symbionts had profound synergistic effect on the activity of this enzyme as compared to control plants (Fig-1B).

The Cadmium stress caused a significant increase in the peroxidase (POD) activity of the

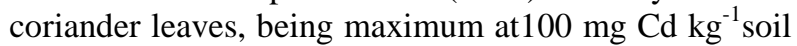
as compared to control. Dual inoculation of AMF and Azotobacter gave enhancement in POD activity. Maximum activity of enzyme was reported when both the microbes were applied at the highest level of cadmium (Fig-1C).

Malondialdehyde (MDA) content, a phytotoxic product of lipid peroxidation, causes membrane disruption which becomes an index of membrane damage in leaves. Increase in $\mathrm{Cd}$ concentration in soil increases the lipid peroxidation and was highest at100 $\mathrm{mg} \mathrm{Cd} \mathrm{kg}{ }^{-1}$ soil (Fig-1D). Its content in single and dual inoculated (AM fungi + Azotobacter) plants increased significantly $(\mathrm{p}<0.05)$ with the increase in $\mathrm{Cd}$ concentration being maximum at $100 \mathrm{mg} \mathrm{Cd} \mathrm{kg}^{-1}$ soil but this increase is less as compared to their respective control plants. However, this decrease in the level of
MDA was found to be maximum in combination treatment of AM fungi+Azotobacter (Fig-1D).

SOD activity had significant increase in leaves exposed to $50 \mathrm{mg} / \mathrm{kg}$ of cadmium and then turned to decline at $100 \mathrm{mg} / \mathrm{kg}$. Whereas in case of inoculated plants SOD activity increases significantly with cadmium concentration. SOD activity reached maximum levels at $100 \mathrm{mg} / \mathrm{kg}$ of cadmium following co-inoculation with AM fungi and Azotobacter (Fig-1).

The catalase (CAT) activity increased significantly with $\mathrm{Cd}$ treatment in both inoculated and uninoculated plants, (Fig-1a). In contrast, the dual application of the AMF and Azotobacterhad maximum effect on the CAT activity compared to the control.

The Cadmium stress and biofertilizer treatment caused a significant increase in the peroxidase (POD) activity of the leaves of plants compared to control. Maximum increase in POD activity was found in case of dual inoculation of AMF and Azotobacter at 100 $\mathrm{mg} / \mathrm{kg}$ of cadmium.

Malondialdehyde (MDA) content which is an index of lipid peroxidation in leaves of both inoculated (AM fungi + Azotobacter) and non-inoculated plants increased significantly $(\mathrm{p}<0.05)$ by the increase in $\mathrm{Cd}$ concentration. The rate of this increase was maximum at $100 \mathrm{mg} \mathrm{kg}^{-1}$ of $\mathrm{Cd}$. The decrease in the level of MDA was found to be maximum in combination treatment of (AM fungi+Azotobacter (Fig-2F).

The two way ANOVA showed that individual effects of inoculation and cadmium and their interaction (inoculation $\times \mathrm{Cd})$ were significant $(\mathrm{p}<0.05)$ for all the measured parameters except interaction effects on CAT and MDA content. Antioxidant enzymes and MDA contents exhibited a negative correlation with growth parameters, presented in Table-2. 

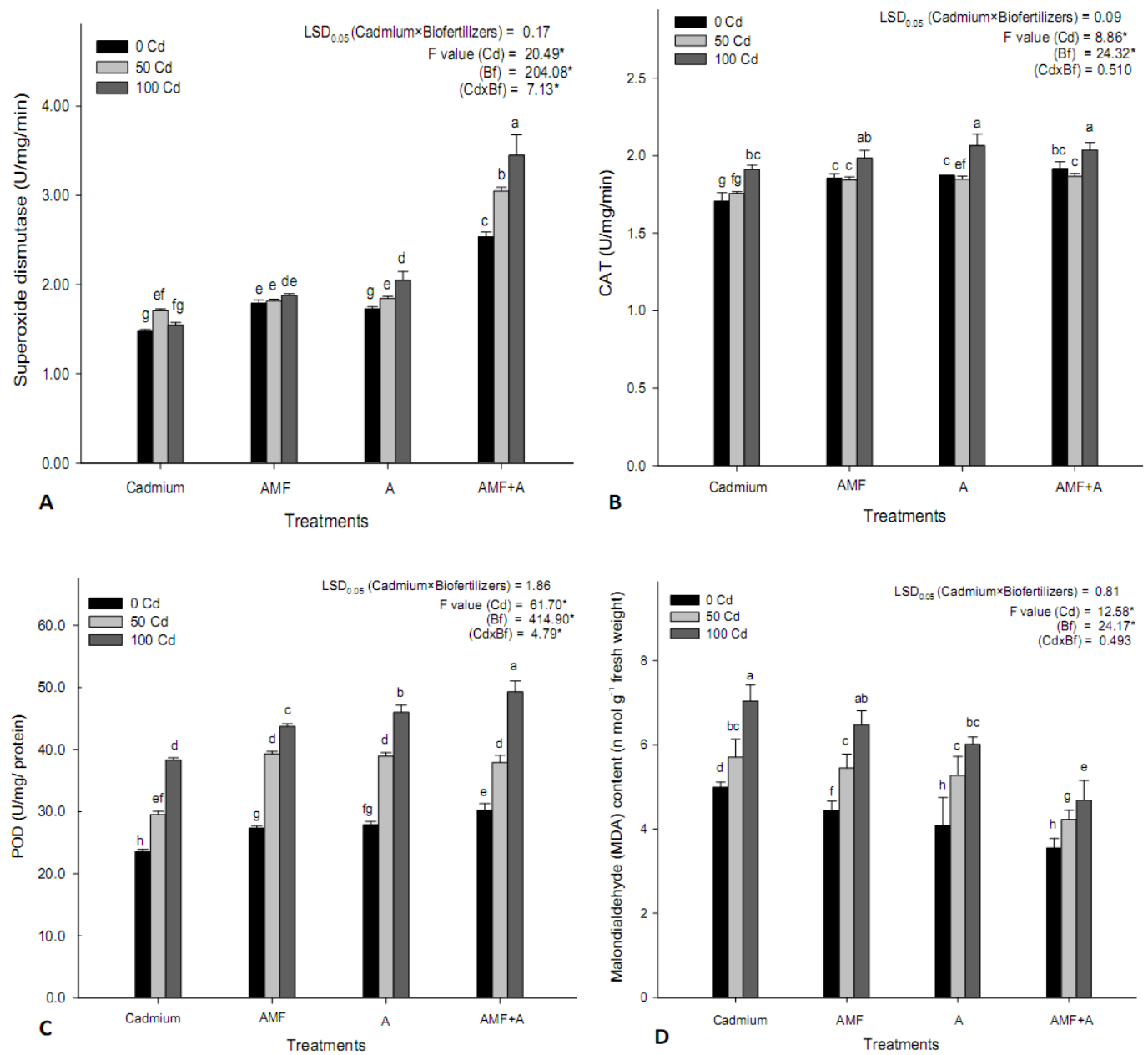

Fig-1

Table-1: Effect of inoculation with biofertilizers on growth parameters of coriander plants subjected to different soil cadmium concentrations

\begin{tabular}{|l|l|l|l|l|l|}
\hline \multicolumn{2}{|l|}{ Treatments } & RL & SL & PFW & PDW \\
\hline Cadmium & Biofertilizers & & & & \\
\hline Control & & $16.87 \pm 0.41 \mathrm{bc}$ & $39.95 \pm 0.39 \mathrm{bcd}$ & $19.88 \pm 0.07 \mathrm{c}$ & $09.37 \pm 0.21 \mathrm{ab}$ \\
\hline 0 & $\mathrm{AMF}_{1} \mathrm{~A}_{0}$ & $19.09 \pm 0.64 \mathrm{a}$ & $45.08 \pm 0.71 \mathrm{a}$ & $21.95 \pm 0.53 \mathrm{~b}$ & $10.41 \pm 0.66 \mathrm{a}$ \\
\cline { 2 - 6 } & $\mathrm{AMF}_{0} \mathrm{~A}_{1}$ & $18.59 \pm 0.39 \mathrm{ab}$ & $45.29 \pm 1.19 \mathrm{a}$ & $22.73 \pm 0.38 \mathrm{~b}$ & $09.74 \pm 0.54 \mathrm{a}$ \\
\cline { 2 - 6 } & $\mathrm{AMF}_{1} \mathrm{~A}_{1}$ & $19.82 \pm 0.62 \mathrm{a}$ & $45.28 \pm 0.37 \mathrm{a}$ & $25.32 \pm 0.90 \mathrm{a}$ & $11.96 \pm 0.62 \mathrm{a}$ \\
\hline \multirow{5}{*}{50} & $\mathrm{AMF}_{0} \mathrm{~A}_{0}$ & $13.03 \pm 0.09 \mathrm{~d}$ & $32.25 \pm 1.68 \mathrm{f}$ & $16.50 \pm 0.98 \mathrm{~d}$ & $07.22 \pm 0.61 \mathrm{c}$ \\
\cline { 2 - 6 } & $\mathrm{AMF}_{1} \mathrm{~A}_{0}$ & $16.29 \pm 0.55 \mathrm{c}$ & $37.89 \pm 1.21 \mathrm{de}$ & $19.00 \pm 0.57 \mathrm{c}$ & $07.34 \pm 0.69 \mathrm{bc}$ \\
\cline { 2 - 6 } & $\mathrm{AMF}_{0} \mathrm{~A}_{1}$ & $16.09 \pm 1.96 \mathrm{c}$ & $37.33 \pm 1.86 \mathrm{e}$ & $18.81 \pm 0.99 \mathrm{c}$ & $07.25 \pm 0.38 \mathrm{c}$ \\
\cline { 2 - 6 } & $\mathrm{AMF}_{1} \mathrm{~A}_{1}$ & $16.38 \pm 1.29 \mathrm{c}$ & $39.33 \pm 1.76 \mathrm{cde}$ & $19.85 \pm 0.44 \mathrm{c}$ & $07.30 \pm 0.37 \mathrm{c}$ \\
\hline \multirow{5}{*}{100} & $\mathrm{AMF}_{0} \mathrm{~A}_{0}$ & $09.63 \pm 0.35 \mathrm{e}$ & $25.24 \pm 1.19 \mathrm{j}$ & $09.62 \pm 0.64 \mathrm{f}$ & $04.45 \pm 0.29 \mathrm{~d}$ \\
\cline { 2 - 6 } & $\mathrm{AMF}_{1} \mathrm{~A}_{0}$ & $10.94 \pm 0.80 \mathrm{e}$ & $27.71 \pm 0.36 \mathrm{ij}$ & $13.50 \pm 0.76 \mathrm{e}$ & $05.67 \pm 0.28 \mathrm{~cd}$ \\
\cline { 2 - 6 } & $\mathrm{AMF}_{0} \mathrm{~A}_{1}$ & $10.80 \pm 0.26 \mathrm{e}$ & $27.77 \pm 0.69 \mathrm{hij}$ & $13.17 \pm 0.60 \mathrm{e}$ & $05.67 \pm 0.64 \mathrm{~cd}$ \\
\cline { 2 - 6 } & $\mathrm{AMF}_{1} \mathrm{~A}_{1}$ & $11.98 \pm 0.07 \mathrm{de}$ & $28.47 \pm 0.87 \mathrm{ghi}$ & $16.48 \pm 2.30 \mathrm{~d}$ & $05.83 \pm 0.52 \mathrm{~cd}$ \\
\hline LSD at 0.05\% & $\mathbf{1 . 7 8 2 6 6}$ & $\mathbf{2 . 5 4 8 5 6}$ & $\mathbf{1 . 8 6 4 8}$ & $\mathbf{2 . 0 4 2 4}$ \\
\hline F- value & & & & $16.155^{*}$ & $3.615^{*}$ \\
\hline BF & df $(3)$ & $7.229 *$ & $8.885^{*}$ & $102.435^{*}$ & $96.410^{*}$ \\
\hline Cadmium & df $(2)$ & $94.387 *$ & $210.481 *$ & 0.787 & 1.505 \\
\hline Interaction & df $(6)$ & 0.350 & 0.670 & & \\
\hline
\end{tabular}


Table-2: Correlation among growth and antioxidant enzyme activity of coriander (Coriandrum sativum L.) under diferent treatments of cadmium and biofertilizers

\begin{tabular}{|c|c|c|c|c|c|c|c|c|}
\hline Attributes & $\begin{array}{l}\text { Root } \\
\text { length }\end{array}$ & $\begin{array}{l}\text { Shoot } \\
\text { length }\end{array}$ & $\begin{array}{l}\text { Plant } \\
\text { fresh } \\
\text { weight }\end{array}$ & $\begin{array}{l}\text { Plant } \\
\text { dry } \\
\text { weight } \\
\end{array}$ & $\begin{array}{l}\text { Superoxide } \\
\text { dismutase }\end{array}$ & Catalase & Peroxidase & $\begin{array}{l}\text { Malanoaldehyde } \\
\text { content }\end{array}$ \\
\hline Root length & 1 & & & & & & & \\
\hline Shoot length & $0.909 * *$ & 1 & & & & & & \\
\hline Plant fresh weight & $0.902 * *$ & $0.892 * *$ & 1 & & & & & \\
\hline Plant dry weight & $0.848 * *$ & $0.854 * *$ & $0.853 * *$ & 1 & & & & \\
\hline $\begin{array}{l}\text { Superoxide } \\
\text { dismutase }\end{array}$ & $-0.007 \mathrm{~ns}$ & $-0.064 n s$ & $0.131 \mathrm{~ns}$ & $-0.055 \mathrm{~ns}$ & 1 & & & \\
\hline Catalase & $-0.394 *$ & $\begin{array}{l}- \\
0.446^{* *}\end{array}$ & $-0.361 *$ & $-0.328 \mathrm{~ns}$ & $0.487 * *$ & 1 & & \\
\hline Peroxidase & $-\overline{0.641 * *}$ & $\begin{array}{l}- \\
0.703 * *\end{array}$ & $-0.570 * *$ & $-0.706 * *$ & $0.476 * *$ & $0.692 * *$ & 1 & \\
\hline $\begin{array}{l}\text { Malainoaldehyde } \\
\text { content }\end{array}$ & $\begin{array}{l}- \\
0.742 * *\end{array}$ & $\begin{array}{l}- \\
0.721 * *\end{array}$ & $-0.769 * *$ & $-0.635^{* *}$ & $-0.402 *$ & $0.157 \mathrm{~ns}$ & $0.365^{*}$ & 1 \\
\hline
\end{tabular}

\section{DISCUSSION}

In the present experiment, the application of bio-fertilizers (alone and in combination) was found favourable to abate the cadmium stress in coriandrum sativum. These results are in consistent withthe previous works that cadmium had a toxic effect on growth whereas addition of bio-fertilizer helps in promoting growth under cadmium stress [67-71]. The presence of cadmium in the soil inhibits plants growth by altering the plant metabolism even at low concentration [72]. The effect of inoculation of AM fungi and Azotobacter (alone or in combination) on the vegetative growth of coriander was significantly higher as compared to control plants. A possible mechanism of this eff ect is the ability of AMF to bind heavy metals by fungal hyphae outside and inside the roots [73]. Azotobacter is able to produce plant hormones or hormone-like substances which can promote plant growth [74-76]. AMF are known to affect plant growth and health by improving mineral nutrition [77] and increasing resistance or tolerance to biotic [78, 79] as well as abiotic stress [80]. Both AMF and Azotobacter complement each other in their role in $\mathrm{N}_{2}$-fixation, phytohormone production, P-solubilization, and increasing surface absorption. The positive synergistic interactions between $\mathrm{AM}$ fungi and various $\mathrm{N}_{2}$-fixing bacteria is the basis of application of these microbes as biofertilizer in the mycorrhizosphere [81]. These microbes are regulated for their own benefit, which in turn benefits the host plant.

At the time of oxidative stress due to metal, membranes are considered as the primary sites of injury and its destabilization, lipid peroxidation and consequent disruption is directly correlated with the production of a phytotoxic product called as MDA [82, 83]. It is considered as themost damaging process known to occur in every living organism. Peroxidation of lipid further boosted gradually in proportion to increased concentration of $\mathrm{Cd}$ in the soil as compared to unstressed conditions [84]. MDA content of AM and Azotobacter inoculated plants was lesser than in the non-inoculated plants even under metal treatments. Synergistic interaction of microbes further decreased the production of MDA in stressed plants. Similar results were found in canola [85], wheat [86], Cajanus [87], isabgol [71].

Cd toxicity induced oxidative stress in plants by the formation of ROS [88, 89], Excess ROS production can cause oxidative damage to biomolecules such as lipid, protein and nucleic acids, and disrupt cellular metabolism $[90,91]$. Plants cope with oxidative stress by using antioxidant enzymes such as SOD, CAT, and POD which are responsible for scavenging excessively accumulated ROS in plants under stress conditions [92, 93].

SOD is called the cell's first line of defense against ROS [94] because superoxide radical production via one electron reduction of triplet oxygen is a precursor to several other highly reactive species and is a starting point for ROS biosynthesis, oxidative stress, and redox regulation in plants [95]. So that control over the steady state of superoxide concentration by SOD constitutes an important protective mechanism [96]. In the present investigation, results showed that the SOD activity was first increased and declined slightly at higher concentration of cadmium. The SOD activity showed an increase and in some, a reduction under abiotic stresses [97]. An increase in SOD activity could possibly be the result of both a direct effect of heavy metalions and an indirect effect mediated via an increase in levels of superoxide radicals [98, 99], which in turn may be associated with an induction of genes of SOD by superoxide-mediated signal transduction [31, 100]. Liu et al., [101] found that AM fungi improved the capability of ROS scavenging and reduced $\mathrm{Cd}$ concentration in plants to alleviate Cd stress. The changes in SOD activity under Azotobacter treatments can be also a consequence of an altered synthesis and accumulation of less active enzymes and/or of a higher turnover of SODs [102]. 
SOD activity reached maximum levels following coinoculation with AM fungi and bacteria [103].

In our study, an increased level in CAT activity was found with the increase in the concentration of $\mathrm{Cd}$ in soil. CAT participates in the main defense system against accumulation and toxicity of ROS, such as $\mathrm{H}_{2} \mathrm{O}_{2}$, and canplay a key role in controlling $\mathrm{H}_{2} \mathrm{O}_{2}$ levels in plant cells [29]. CAT catalyzes the dismutation of $\mathrm{H}_{2} \mathrm{O}_{2}$ into $\mathrm{H}_{2} \mathrm{O}$ and $\mathrm{O}_{2}$ and has been found to increase under stress which in turns protected plants from oxidative damage [104]. A further increase in CAT activity was observed in plants following the-inoculation of AMF and Azotobacter. The synergistic interaction of microbes further enhanced the activity of this enzyme. Our result coincides with karthikeyan [75], Azcon et al., [103] as well as Lin and Kao [105].

In the present investigation, POD activity was increased with the elevation in the level of $\mathrm{Cd}$ in soil. Azotobacter or AM fungi symbiosis increased the activity of enzyme, however their interaction had greater effect. These results suggest that symbionts colonization reduces ROS elevated stress. POD not only scavenges $\mathrm{H}_{2} \mathrm{O}_{2}$, but also catalyzes the synthesis of cell wall [106], modifies mechanical properties of the cell wall and cell membrane integrity of plant leaves under stress conditions [107]. Zhang et al., [108] observed decreased oxidative stress in Vicia faba by intricating antioxidant defense system due to POD grown in soil contaminated with Cd following $\mathrm{G}$. mosseae treatment.

All the antioxidant (SOD, CAT and POD) activities in case of inoculated plants were significantly higher than those of uninoculated plants at all concentrations, suggesting that biofertilizers could improve the antioxidant enzyme systems to alleviate destructive stress. Plants with high concentration of antioxidants have been reported to have greater resistance to this oxidative damage [109-111]. The antioxidant activities further increased with the application of biofertilizers was a significant improvement [29, 103, 112, 113].

\section{CONCLUSION}

Cd causes oxidative stress due to reduction in growth, alterations of antioxidant enzymes and increase of MDA content in plants. Use of biofertilizer in the form of AM fungi and Azotobacter played a potential role in the increment of growth and antioxidant activity and thereby decrease oxidative stress. Co-inoculation of both the microbes had positive synergistic interaction on growth and antioxidant activity. However, combined interaction declined the MDA content. Therefore, microbes ameliorated $\mathrm{Cd}$ stress by the increase of antioxidant activity and decline of membrane damage and application of biofertilizers is cost efficient, eco- friendly, easier to use, alleviates Cd stress and enhances the tolerance to cadmium stress in Coriandrum sativum.

\section{ACKNOWLEDGEMENT}

The author is deeply thankful to the Chairman, Department of Botany, A.M.U., Aligarh for providing necessary facilities for carrying out this research.

\section{REFRENCES}

1. Gisbert, C., Ros, R., De Haro, A., Walker, D. J., Bernal, M. P., Serrano, R., \& Navarro-Aviñó, J. (2003). A plant genetically modified that accumulates $\mathrm{Pb}$ is especially promising for phytoremediation. Biochemical and biophysical research communications, 303(2), 440-445.

2. Munzuroglu, O., \& Geckil, H. (2002). Effects of metals on seed germination, root elongation, and coleoptile and hypocotyl growth in Triticum aestivum and Cucumis sativus. Archives of Environmental Contamination and Toxicology, 43(2), 203-213.

3. Di Toppi, L. S., \& Gabbrielli, R. (1999). Response to cadmium in higher plants. Environmental and experimental botany, 41(2), 105-130.

4. Zulfiqar, S., Shahnawaz, S., Ali, M., Bhutta, A. M., Iqbal, S., Hayat, S., ... \& Iqbal, F. (2012). Detection of Babesia bovis in blood samples and its effect on the hematological and serum biochemical profile in large ruminants from Southern Punjab. Asian Pacific journal of tropical biomedicine, 2(2), 104-108.

5. Angelone, M., \& Bini, C. (1992) In: Adriano D.C. (ed.), Biogeochemistry of trace metals, 19-60.

6. Di Toppi, L. S., \& Gabbrielli, R. (1999). Response to cadmium in higher plants. Environmental and experimental botany, 41(2), 105-130.

7. Solís-Domínguez FA, González-Chávez MC, Carrillo-González R, Rodríguez-Vázquez R. Accumulation and localization of cadmium in Echinochloa polystachya grown within a hydroponic system. Journal of hazardous materials. 2007 Mar 22;141(3):630-6.

8. Ranieri, A., Castagna, A., Scebba, F., Careri, M., Zagnoni, I., Predieri, G., ... \& di Toppi, L. S. (2005). Oxidative stress and phytochelatin characterisation in bread wheat exposed to cadmium excess. Plant Physiology and Biochemistry, 43(1), 45-54.

9. Nazar, R., Iqbal, N., Masood, A., Khan, M. I. R., Syeed, S., \& Khan, N. A. (2012). Cadmium toxicity in plants and role of mineral nutrients in its alleviation. American Journal of Plant Sciences, 3(10), 1476-1489.

10. Sandalio, L. M., Dalurzo, H. C., Gomez, M., Romero- Puertas, M. C., \& Del Rio, L. A. (2001). Cadmium- induced changes in the growth and oxidative metabolism of pea plants. Journal of experimental botany, 52(364), 2115-2126. 
11. Arora, A., Sairam, R. K., \& Srivastava, G. C. (2002). Oxidative stress and antioxidative system in plants. Current science, 1227-1238.

12. Foyer, C. H., \& Noctor, G. (2003). Redox sensing and signalling associated with reactive oxygen in chloroplasts, peroxisomes and mitochondria. Physiologia plantarum, 119(3), 355-364.

13. Cho, U. H., \& Seo, N. H. (2005). Oxidative stress in Arabidopsis thaliana exposed to cadmium is due to hydrogen peroxide accumulation. Plant Science, 168(1), 113-120.

14. Jin, K., Zhu, Y., Sun, Y., Mao, X. O., Xie, L., \& Greenberg, D. A. (2002). Vascular endothelial growth factor (VEGF) stimulates neurogenesis in vitro and in vivo. Proceedings of the National Academy of Sciences, 99(18), 11946-11950.

15. Moldovan, L., \& Moldovan, N. I. (2004). Oxygen free radicals and redox biology of organelles. Histochemistry and cell biology, 122(4), 395-412.

16. Halliwell, B., \& Gutteridge, J. M. C. (2006) Free Radicals in Biology and Medicine, Ed 4. Clarendon Press, Oxford.

17. Skórzyńska-Polit, E., \& Krupa, Z. (2006). Lipid peroxidation in cadmium-treated Phaseolus coccineus plants. Archives of Environmental Contamination and Toxicology, 50(4), 482-487.

18. Vajo, Z., Tamas, F., Sinka, L., \& Jankovics, I. (2010). Safety and immunogenicity of a 2009 pandemic influenza A H1N1 vaccine when administered alone or simultaneously with the seasonal influenza vaccine for the 2009-10 influenza season: a multicentre, randomised controlled trial. The Lancet, 375(9708), 49-55.

19. Zhiqiang, X. U., Qixing, Z. H. O. U., \& Weitao, L. I. U. (2009). Joint effects of cadmium and lead on seedlings of four Chinese cabbage cultivars in northeastern China. Journal of Environmental Sciences, 21(11), 1598-1606.

20. Singh, N., \& Gilca, M. (2010). Herbal Medicine: Science Embraces Tradition: a New Insight Into Ancient Ayurveda. Lambert Academic Publishing (Germany), 51-67.

21. Ruley, A. T., Sharma, N. C., \& Sahi, S. V. (2004). Antioxidant defense in a lead accumulating plant, Sesbania drummondii. Plant Physiology and Biochemistry, 42(11), 899-906.

22. Semane, B., Dupae, J., Cuypers, A., Noben, J. P., Tuomainen, M., Tervahauta, A., ... \& Vangronsveld, J. (2010). Leaf proteome responses of Arabidopsis thaliana exposed to mild cadmium stress. Journal of Plant Physiology, 167(4), 247254.

23. Qadir, M., \& Oster, J. D. (2004). Crop and irrigation management strategies for saline-sodic soils and waters aimed at environmentally sustainable agriculture. Science of the total environment, 323(1-3), 1-19.
24. Rahmanian, O., Chen, C. F., \& DeVoe, D. L. (2012). Microscale patterning of thermoplastic polymer surfaces by selective solvent swelling. Langmuir, 28(35), 12923-12929.

25. Schutzendubel, A., \& Polle, A. (2002). Plant responses to abiotic stresses: heavy metalinduced oxidative stress and protection by mycorrhization. Journal of experimental botany, 53(372), 1351-1365.

26. Gratão, P. L., Polle, A., Lea, P. J., \& Azevedo, R. A. (2005). Making the life of heavy metal-stressed plants a little easier. Functional plant biology, 32(6), 481-494.

27. Michalak, A. (2006). Phenolic compounds and their antioxidant activity in plants growing under heavy metal stress. Polish Journal of Environmental Studies, 15(4), 523-530.

28. Liu, Y., Zeng, G., Wang, X., Chen, B., Song, H., \& Xu, L. (2010). Cadmium accumulation in Vetiveria zizanioides and its effects on growth, physiological and biochemical characters. Bioresource Technology, 101(16), 6297-6303.

29. Garg, N., \& Aggarwal, N. (2011). Effects of interactions between cadmium and lead on growth, nitrogen fixation, phytochelatin, and glutathione production in mycorrhizal Cajanus cajan (L.) Millsp. Journal of plant growth regulation, 30(3), 286-300.

30. Alscher, R. G., Erturk, N., \& Heath, L. S. (2002). Role of superoxide dismutases (SODs) in controlling oxidative stress in plants. Journal of experimental botany, 53(372), 1331-1341.

31. Fatima, R. A., \& Ahmad, M. (2005). Certain antioxidant enzymes of Allium cepa as biomarkers for the detection of toxic heavy metals in wastewater. Science of the Total Environment, 346(1-3), 256-273.

32. Kono, Y., \& Fridovich, I. (1983). Inhibition and reactivation of Mn-catalase. Implications for valence changes at the active site manganese. Journal of Biological Chemistry, 258(22), 13646-13648.

33. Scandalios, J. G. (1993). Oxygen stress and superoxide dismutases. Plant physiology, 101(1), 7-12.

34. De Gara, L., de Pinto, M. C., \& Tommasi, F. (2003). The antioxidant systems vis-à-vis reactive oxygen species during plant-pathogen interaction. Plant Physiology and Biochemistry, 41(10), 863-870.

35. Jablonski, P. P., \& Anderson, J. W. (1982). Lightdependent reduction of hydrogen peroxide by ruptured pea chloroplasts. Plant Physiology, 69(6), 1407-1413.

36. Srivastava, M. B., Chandrakasan, A. P., \& Brodersen, R. W. (1996). Predictive system shutdown and other architectural techniques for energy efficient programmable computation. IEEE 
Transactions on Very Large Scale Integration (VLSI) Systems, 4(1), 42-55.

37. Hause, B., \& Fester, T. (2005). Molecular and cell biology of arbuscular mycorrhizal symbiosis. Planta, 221(2), 184-196.

38. González-Guerrero, M., Cano, C., Azcón-Aguilar, C., \& Ferrol, N. (2007). GintMT1 encodes a functional metallothionein in Glomus intraradices that responds to oxidative stress. Mycorrhiza, 17(4), 327-335.

39. Saraswat, S., \& Rai, J. P. N. (2011). Mechanism of metal tolerance and detoxification in mycorrhizal fungi. In Biomanagement of metal-contaminated soils (pp. 225-240). Springer, Dordrecht.

40. Garg, N., \& Bhandari, P. (2013). Plant Biosystems 2013- An International Journal Dealing with all Aspects of Plant Biology: Cadmium toxicity in crop plants and its alleviation by arbuscular mycorrhizal (AM) fungi: An overview, Plant Biosystems - An International Journal Dealing with all Aspects of Plant Biology: Official J Societa Botanica Italiana.

41. Brachmann, A., \& Parniske, M. (2006). The most important symbiosis on earth. Soil Biol, 4, 239.

42. Bompadre, M. J., Pérgola, M., Fernández Bidondo, L., Colombo, R. P., Silvani, V. A., Pardo, A. G., ... \& Godeas, A. M. (2014). Evaluation of arbuscular mycorrhizal fungi capacity to alleviate abiotic stress of olive (Olea europaea L.) plants at different transplant conditions. The Scientific World Journal, 2014.

43. Davies Jr, F. T., Saraiva Grossi, J. A., Carpio, L., \& Estrada-Luna, A. A. (2000). Colonization and growth effects of the mycorrhizal fungus Glomus intraradicies in a commercial nursery container production system. Journal of Environmental Horticulture, 18(4), 247-251.

44. Azcón-Aguilar, C., \& Barea, J. M. (1997). Applying mycorrhiza biotechnology to horticulture: significance and potentials. Scientia Horticulturae, 68(1-4), 1-24.

45. Bonfante, P., \& Genre, A. (2010). Mechanisms underlying beneficial plant-fungus interactions in mycorrhizal symbiosis. Nature communications, 1 , 48.

46. Liu, J. L., \& Srivastava, H. M. (2004). Certain properties of the Dziok-Srivastava operator. Applied Mathematics and Computation, 159(2), 485-493.

47. Stefan, M. I., Edelstein, S. J., \& Le Novere, N. (2008). An allosteric model of calmodulin explains differential activation of PP2B and CaMKII. Proceedings of the National Academy of Sciences, 105(31), 10768-10773.

48. Brown, G. L., \& Roshko, A. (1974). On density effects and large structure in turbulent mixing layers. Journal of Fluid Mechanics, 64(4), 775816.

49. Wani, P. A., Khan, M. S., \& Zaidi, A. (2007). Synergistic effects of the inoculation with nitrogen- fixing and phosphate- solubilizing rhizobacteria on the performance of field- grown chickpea. Journal of Plant Nutrition and Soil Science, 170(2), 283-287.

50. Ahmad, F., Ahmad, I., \& Khan, M. S. (2008). Screening of free-living rhizospheric bacteria for their multiple plant growth promoting activities. Microbiological research, 163(2), 173181.

51. Saharan, B. S., \& Nehra, V. (2011). Plant growth promoting rhizobacteria: a critical review. Life $S c i$ Med Res, 2l(1), 30.

52. Zaidi, A., Khan, M. S., \& Amil, M. D. (2003). Interactive effect of rhizotrophic microorganisms on yield and nutrient uptake of chickpea (Cicer arietinum L.). European journal of agronomy, 19(1), 15-21.

53. Zaidi, A., \& Khan, M. S. (2006). Co-inoculation effects of phosphate solubilizing microorganisms and Glomus fasciculatum on green gramBradyrhizobium symbiosis. Turkish Journal of Agriculture and Forestry, 30(3), 223-230.

54. Kumar, V., \& Narula, N. (1999). Solubilization of inorganic phosphates by Azotobacter chroococcum mutants and their effect on seed emergence of wheat. Biol. Fertil. Soil, 28, 301305.

55. Narula, N., Kumar, V., Behl, R. K., Deubel, A., Gransee, A., \& Merbach, W. (2000). Effect of Psolubilizing Azotobacter chroococcum on N, P, K uptake in $\mathrm{P}$ - responsive wheat genotypes grown under greenhouse conditions. Journal of Plant Nutrition and Soil Science, 163(4), 393-398.

56. Kumar, V., Behl, R. K., \& Narula, N. (2001). Establishment of phosphate-solubilizing strains of Azotobacter chroococcum in the rhizosphere and their effect on wheat cultivars under green house conditions. Microbiological research, 156(1), $87-$ 93.

57. Cardoso, A. P., Mirione, E., Ernesto, M., Massaza, F., Cliff, J., Haque, M. R., \& Bradbury, J. H. (2005). Processing of cassava roots to remove cyanogens. Journal of Food Composition and Analysis, 18(5), 451-460.

58. Figueira, J., Greco, S., \& Ehrgott, M. (Eds.). (2005). Multiple criteria decision analysis: state of the art surveys (Vol. 78). Springer Science \& Business Media.

59. Corticeiro, S. C., Lima, A. I. G., \& Figueira, E. M. D. A. P. (2006). The importance of glutathione in oxidative status of Rhizobium leguminosarum biovar viciae under $\mathrm{Cd}$ exposure. Enzyme and microbial technology, 40(1), 132-137.

60. Kumar, M. (2013). Crop plants and abiotic stresses. J. Biomol. Res. Ther, 3(1).

61. Zhang, H., Jiang, Y., He, Z., \& Ma, M. (2005). Cadmium accumulation and oxidative burst in garlic (Allium sativum). Journal of plant physiology, 162(9), 977-984. 
62. Zhang, S. H., Reddick, R. L., Piedrahita, J. A., \& Maeda, N. (1992). Spontaneous hypercholesterolemia and arterial lesions in mice lacking apolipoprotein E. Science, 258(5081), 468-471.

63. Zhou, W., \& Leul, M. (1999). Uniconazoleinduced tolerance of rape plants to heat stress in relation to changes in hormonal levels, enzyme activities and lipid peroxidation. Plant Growth Regulation, 27(2), 99-104.

64. Gupta, A. S., Webb, R. P., Holaday, A. S., \& Allen, R. D. (1993). Overexpression of superoxide dismutase protects plants from oxidative stress (induction of ascorbate peroxidase in superoxide dismutase-overexpressing plants). Plant Physiology, 103(4), 1067-1073.

65. Aebi, H. (1984). Catalase in vitro. In Methods in enzymology, 105, 121-126. Academic Press.

66. Bergmeyer, H. U., Gawehn, K., \& Grassl, M. (1974). In: Methods of Enzymatic Analysis (Bergmeyer, H.U. ed.) $2^{\text {nd }}$ Ed., 1, 473-474.

67. Al-Rajhi, A. M. (2013). Impact of biofertilizer Trichoderma harzianum Rifai and the biomarker changes in Eruca sativa L. plant grown in metalpolluted soils. World Applied Sciences Journal, 22(2), 171-180.

68. Arumugam, R., Rajasekaran, S., \& Nagarajan, S. M. (2010). Response of Arbuscular mycorrhizal fungi and Rhizobium inoculation on growth and chlorophyll content of Vigna unguiculata (L) Walp Var. Pusa 151. Journal of Applied Sciences and Environmental Management, 14(4):113-115.

69. Haneef, I., Faizan, S., Perveen, R., \& Kausar, S. (2013). Role of arbuscular mycorrhizal fungi on growth and photosynthetic pigments in (Coriandrum sativum L.) grown under cadmium stress. World J Agric Sci, 9(3), 245-250.

70. Sarhan, T. Z. (2012). Effect of Biofertilizer and Different Levels of Nitrogen (Urea) on Growth, Yield and Quality of Lettuce (Lactuca sativa L.) Ramadi cv. Journal of Agricultural Science and Technology. B, 2(1B):137-141.

71. Haneef, I., Faizan, S., Perveen, R., \& Kausar, S. (2014). Impact of bio-fertilizers and different levels of cadmium on the growth, biochemical contents and lipid peroxidation of Plantago ovata Forsk. Saudi journal of biological sciences, 21(4), 305-310.

72. Hasan, S. A., Fariduddin, Q., Ali, B., Hayat, S., \& Ahmad, A. (2009). Cadmium: toxicity and tolerance in plants. Journal Environmental Biology, 30:165-174.

73. Jian-Feng, H. U. A., Xian-Gui, L. I. N., Jian-Feng, B. A. I., Yu-Fang, S. H. A. O., Rui, Y. I. N., \& Jiang, Q. (2010). Effects of arbuscular mycorrhizal fungi and earthworm on nematode communities and arsenic uptake by maize in arseniccontaminated soils. Pedosphere, 20(2), 163-173.

74. Jaleel, C. A., Manivannan, P., Sankar, B., Kishorekumar, A., Gopi, R., Somasundaram, R.,
\& Panneerselvam, R. (2007). Pseudomonas fluorescens enhances biomass yield and ajmalicine production in Catharanthus roseus under water deficit stress. Colloids and Surfaces B: Biointerfaces, 60(1), 7-11.

75. Karthikeyan, B., Jaleel, C. A., Gopi, R., \& Deiveekasundaram, M. (2007). Alterations in seedling vigour and antioxidant enzyme activities in Catharanthus roseus under seed priming with native diazotrophs. Journal of Zhejiang University Science B, 8(7), 453-457.

76. Brown, M. E. (1968). Production of plant growth substances by Azotobacter chroococcum. Microbiology, 53(1), 135-144.

77. Clark, R. B., \& Zeto, S. K. (2000). Mineral acquisition by arbuscular mycorrhizal plants. Journal of plant Nutrition, 23(7), 867-902.

78. Cordier, C., Trouvelot, A., Gianinazzi, S., \& Gianinazzi-Pearson, V. (1996). Arbuscular mycorrhiza technology applied to micropropagated Prunus avium and to protection against Phytophthora cinnamomi. Agronomie, 16: 676-688.

79. Trotta, A., Varese, G. C., Gnavi, E., Fusconi, A., Sampo, S., \& Berta, G. (1996). Interactions between the soilborne root pathogenPhytophthora nicotianae var. parasitica and the arbuscular mycorrhizal fungusGlomus mosseae in tomato plants. Plant and Soil, 185(2), 199-209.

80. Turnau, K., \& Haselwandter, K. (2002). Arbuscular mycorrhizal fungi, an essential component of soil microflora in ecosystem restoration. In Mycorrhizal technology in agriculture (pp. 137-149). Birkhäuser, Basel.

81. Bansal, M., Chamola, B. P., Sarwar, N., \& Mukerji, K. G. (2002). Mycorrhizosphere: Interactions between rhizosphere microflora. Mycorrhizal Biology. Kluwer Academic/Planum Publishers, New York, 143-152.

82. Emrouznejad, A., \& Marra, M. (2014). Ordered weighted averaging operators 1988-2014: A citation- based literature survey. International Journal of Intelligent Systems, 29(11), 994-1014.

83. Zhou, Y., Xu, Z., \& Yoon, J. (2011). Fluorescent and colorimetric chemosensors for detection of nucleotides, FAD and NADH: highlighted research during 2004-2010. Chemical Society Reviews, 40(5), 2222-2235.

84. Gill, S. S., Khan, N. A., \& Tuteja, N. (2012). Cadmium at high dose perturbs growth, photosynthesis and nitrogen metabolism while at low dose it up regulates sulfur assimilation and antioxidant machinery in garden cress (Lepidium sativum L.). Plant Science, 182, 112-120.

85. Habibzadeh, F., Sorooshzadeh, A., Sanavy, S. A. M. M., \& Pirdashti, H. (2012). Effect of seed inoculation and foliar application of biofertilizers on some biochemical and morphological characteristics of waterlogged-canola. The Journal of American Science, 8(6), 62-68. 
86. Abad, A. K. J., \& Khara, J. (2007). Effect of cadmium toxicity on the level of lipid peroxidation and antioxidative enzymes activity in wheat plants colonized by arbuscular mycorrhizal fungi. Pakistan Journal of Biological Sciences, 10(14), 2413-2417.

87. Garg, N., \& Aggarwal, N. (2012). Effect of mycorrhizal inoculations on heavy metal uptake and stress alleviation of Cajanus cajan (L.) Millsp. genotypes grown in cadmium and lead contaminated soils. Plant Growth Regulation, 66(1), 9-26.

88. Hegedüs, A., Erdei, S., \& Horváth, G. (2001). Comparative studies of $\mathrm{H} 2 \mathrm{O} 2$ detoxifying enzymes in green and greening barley seedlings under cadmium stress. Plant Science, 160(6), 1085-1093.

89. Olmos, E., Martínez- Solano, J. R., Piqueras, A., \& Hellín, E. (2003). Early steps in the oxidative burst induced by cadmium in cultured tobacco cells (BY- 2 line). Journal of Experimental Botany, 54(381), 291-301.

90. Ali, M. B., Vajpayee, P., Tripathi, R. D., Rai, U. N., Singh, S. N., \& Singh, S. P. (2003). Phytoremediation of lead, nickel, and copper by Salix acmophylla Boiss.: role of antioxidant enzymes and antioxidant substances. Bulletin of environmental contamination and toxicology, 70(3), 462-469.

91. Yu, X. Z., \& Gu, J. D. (2007). Metabolic responses of weeping willows to selenate and selenite. Environmental Science and Pollution Research-International, 14(7), 510-517.

92. Hana, S., Rachid, R., Ibtissem, S., Houria, B., \& Mohammed-Réda, D. (2008). Induction of antioxidative enzymes by cadmium stress in tomato (Lycopersicon esculentum). African Journal of plant science, 2(8), 72-76.

93. Srivastava, R., Khan, R., \& Manzoor, N. (2011). Responses of cadmium exposures on growth, physio-biochemical characteristics and the antioxidative defence system of soybean (Glycine max L.). Journal of Phytology, 3: 20-25.

94. Fatima, R. A., \& Ahmad, M. (2005). Certain antioxidant enzymes of Allium cepa as biomarkers for the detection of toxic heavy metals in wastewater. Science of the Total Environment, 346(1-3), 256-273.

95. Arthikala, M. K., Nava, N., \& Quinto, C. (2015). Effect of Rhizobium and arbuscular mycorrhizal fungi inoculation on electrolyte leakage in Phaseolus vulgaris roots overexpressing RbohB. Plant signaling \& behavior, 10(4), e1011932.

96. Fridovich, I. (1997). Superoxide anion radical (O. 2), superoxide dismutases, and related matters. Journal of Biological Chemistry, 272(30), 18515-18517.

97. Muthukumarasamy, M., Gupta, S. D., \& Panneerselvam, R. (2000). Enhancement of peroxidase, polyphenol oxidase and superoxide dismutase activities by triadimefon in $\mathrm{NaCl}$ stressed Raphanus sativus L. Biologia Plantarum, 43(2), 317-320.

98. Kopyra, M., \& Gwóźdź, E. A. (2003). Nitric oxide stimulates seed germination and counteracts the inhibitory effect of heavy metals and salinity on root growth of Lupinus luteus. Plant Physiology and Biochemistry, 41(11-12), 1011-1017.

99. Verma, S., \& Dubey, R. S. (2003). Lead toxicity induces lipid peroxidation and alters the activities of antioxidant enzymes in growing rice plants. Plant Science, 164(4), 645-655.

100. Gupta, D. K., Nicoloso, F. T., Schetinger, M. R. C., Rossato, L. V., Pereira, L. B., Castro, G. Y., ... \& Tripathi, R. D. (2009). Antioxidant defense mechanism in hydroponically grown Zea mays seedlings under moderate lead stress. Journal of Hazardous Materials, 172(1), 479-484.

101. Liu, Z., Chen, W., \& He, X. (2011). Cadmiuminduced changes in growth and antioxidative mechanisms of a medicine plant (Lonicera japonica Thunb.). Journal of Medicinal Plants Research, 5(8), 1411-1417.

102. Chaparzadeh, N., D'Amico, M. L., Khavari-Nejad, R. A., Izzo, R., \& Navari-Izzo, F. (2004). Antioxidative responses of Calendula officinalis under salinity conditions. Plant Physiology and Biochemistry, 42(9), 695-701.

103. Azcón, R., del Carmen Perálvarez, M., Biro, B., Roldán, A., \& Ruíz-Lozano, J. M. (2009). Antioxidant activities and metal acquisition in mycorrhizal plants growing in a heavy-metal multicontaminated soil amended with treated lignocellulosic agrowaste. applied soil ecology, 41(2), 168-177.

104. Khan, N. A., Hemmelgarn, B., Padwal, R., Larochelle, P., Mahon, J. L., Lewanczuk, R. Z., ... \& Schiffrin, E. L. (2007). The 2007 Canadian Hypertension Education Program recommendations for the management of hypertension: Part 2-therapy. Canadian Journal of Cardiology, 23(7), 539-550.

105. Lin, C. C., \& Kao, C. H. (2000). Effect of $\mathrm{NaCl}$ stress on $\mathrm{H} 2 \mathrm{O} 2$ metabolism in rice leaves. Plant Growth Regulation, 30(2), 151-155.

106. Baker, C. J., Deahl, K., Domek, J., \& Orlandi, E. W. (2000). Scavenging of $\mathrm{H} 2 \mathrm{O} 2$ and production of oxygen by horseradish peroxidase. Archives of biochemistry and biophysics, 382(2), 232-237.

107. Ekmekçi, Y., Tanyolac, D., \& Ayhan, B. (2008). Effects of cadmium on antioxidant enzyme and photosynthetic activities in leaves of two maize cultivars. Journal of plant physiology, 165(6), 600-611.

108. Zhang, X. H., Smith, S. E., \& Smith, F. A. (2006). Effects of Glomus mosseae on the toxicity of heavy metals to Vicia faba. Journal of Environmental Sciences, 18(4), 721-726. 
109. Borde, M., Dudhane, M., \& Jite, P. (2011). Growth photosynthetic activity and antioxidant responses of mycorrhizal and non-mycorrhizal bajra (Pennisetum glaucum) crop under salinity stress condition. Crop Protection, 30(3), 265-271.

110. Dionisio-Sese, M. L., \& Tobita, S. (1998). Antioxidant responses of rice seedlings to salinity stress. Plant Science, 135(1), 1-9.

111. Jiang, M., \& Zhang, J. (2002). Involvement of plasma-membrane NADPH oxidase in abscisic acid-and water stress-induced antioxidant defense in leaves of maize seedlings. Planta, 215(6), 10221030.

112. Ordookhani, K., Khavazi, K., Moezzi, A., \& Rejali, F. (2010). Influence of PGPR and AMF on antioxidant activity, lycopene and potassium contents in tomato. African Journal of Agricultural Research, 5(10), 1108-1116.

113. Bhaduri, A. M., \& Fulekar, M. H. (2012). Assessment of arbuscular mycorrhizal fungi on the phytoremediation potential of Ipomoea aquatica on cadmium uptake. 3 Biotech, 2(3), 193-198. 